DE DE GRUYTER OPEN
Journal of Intercultural Management

Vol. 6, No. 3, September 2014, pp. 151-165

DOI 10.2478/joim-2014-0026

Anna Tarabasz*

University of Lodz

\title{
Building competitive advantage in the context of electronic communication with the use of social media
}

\begin{abstract}
In today's turbulent environment it is difficult to imagine a modern company knowingly waives the benefits of electronic communication. Simultaneously there is a multitude of companies that misuse these tools, that makes their actions usually having exactly opposite results of intended. Due to advantages of the Internet as a communication channel and effective advertising medium, more and more companies decide to invest into it. In Poland in 2013, with nearly 7 billion of PLN spent on advertising, more than $21 \%$ was invested in online promotion. Furthermore, Internet as an advertising channel of communication is the only one noting regular annual increase in spending on advertising campaigns in comparison to other media.

This article is an attempt to show the merits of building companys' competitive advantage with the use of Internet and particular regard to social media. It presents both own model on-line communication and the results of research among 11 largest retail banks in Poland and opinions of their 1800 customers.
\end{abstract}

Key words: competitive advantage,electronic communication, social media, crowdsourcing

\section{Introduction}

According to John Powell's words "communication works for those who work at it" (Lind, 2012) creating relationship with customers based on effective communication requires a lot of effort and is a long-term process. This is no different with electronic communication, which nowadays is growing at a dizzying pace. The attractiveness of potential recipients of electronic messages, manifested in the increasing number of Internet users, their level of education, average age, increase of real purchasing power, sensitivity to e-advertising and non-standard consump-

*tarabasz@uni.lodz.pl 
tion of other media, makes more and more companies in Poland decide building a wide range of e-communication tools and invest in online advertising. For many companies online presence is no longer just a "virtual card" but constitutes the lucrative branch of entire business. Forseeing companies perceive electronic communication, particularly through social media, as basis for the future development and the foundations for building a competitive advantage (CA). In today's turbulent environment it is difficult to imagine a modern company knowingly waives numerous benefits of electronic communication. On the other hand, it should be stressed that there is also a large number of companies that misuse these tools. Such actions have usually exactly the opposite result of the intended.

To illustrate the power of the Internet and its latent possibilities as a medium and tool of building a competitive advantage in the subsequent parts of this article will address issues of competitive advantage in the strict sense, advantages of e-communication, the attractiveness of the auditorium, the process (model) of electronic communication and examples of the use of e-communication, with particular emphasis on social media.

\section{Defining competitive advantage}

To understand the importance of electronic communication and social media factors in image building of the company and its market position, it shall be perceived through competition phenomenon and building a competitive advantage prism. If as a first understand process in which market participants are competing to carry out their interests in the context of transaction by providing a more favorable offer from other entities, so the competitive advantage could be theoretically considered as state of achieving superior position against competitors in specific characteristics, conditions or behavior. So understood competitive advantage allows to offer products or services corresponding to customer expectations, but better than its competitors in selected aspects, which can be expressed not only in a higher product quality, its lower price, better service, more complex satisfying customer's needs but also to building superiority in creation of relationships based on perfect communication.

But the truth is that in the literature of the subject the issue of communication, as a factor building competitive advantage remains secondary to traditional porterian differentiation approach (Porter, 1985), basing on cost leadership and strategic differentiation. Though in reality, the issue of communication, with particular emphasis on communicates transmitted over the Internet using social media could be considered as strategic differentiation, however, due to relatively low cost of reaching the customer, usefull in reduction of unnecessary expences, thus an indirect reference to the cost advantage could be sought here also. Quoting the definition of competitive advantage by Porter (1985) advantage of differentiation derives 
from attribute(s) that allow an organization to outperform its competition, such as superior market position, skills, or resources, electronic communication could be entered along with two recent factors. Worth stressing is thoug point of view presented by Rolstadås (1995) that in Porter's view, strategic management should be concerned with building and sustaining competitive advantage, which grows out of value a firm is able to create for its buyers that exceed the firm's cons of creating it.

Such approach seeems to be pararell to one presented by Lubbe (2005) defining competitive advantage as usually referring to characteristics that permit firm to com pete effectively with other firms due to low cost or superior technology, perhaps internationally or Braun (2006). The latter indicates a condition that enables companies to operate in a more efficient or higher manner than the companies it competes with, which results in financial benefits. Those attitudes are also similar to Rogers's approach (Rogers, 2009) underlining factors creating basis for competitive advantage, that have to be unique, superior to competition, sustainable, applicable to multiple business solutions and hard to copy.

The uniqueness of competitive resource/factor is equally stressed also by Nissen (2005) and Barney (1991). The first defines competitive advantage as simply as fact of employing organizational resources that cannot be imitaded readily by competitors. The second points that a firm is said to have a sustained competitive advantage when is implementing a value creating stategy not simultaneously being implemented by any current or potential competitors and while these other firms are unable toduplicate the benefits of this strategy.

Though majority of definitions of CA is very brief and concise i.e. (Kotelnikov, 2007) describing it as an advantage that enables your business to survive against its competiton over a long period of time, there are also ones although more complex (Chaston, 2012; Partners Creating Welath, 2014), yet presenting interesting point of view.

Picture 1. Possible strategic options

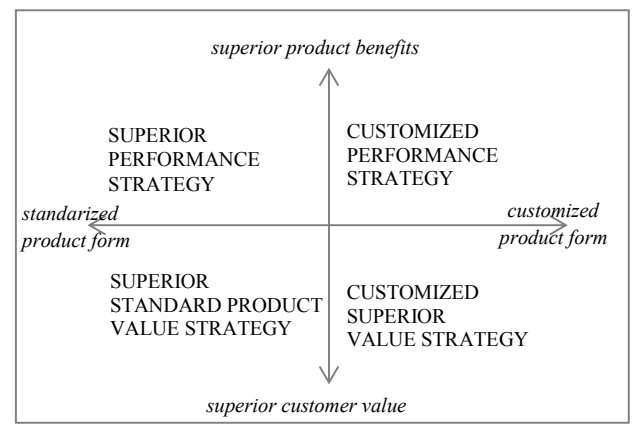

Note. From Strategy for sustainable competitive advantage: surviving declining demand and China's global development (p. 129), by I. Chaston (2012), New York, NY: Routledge. Copyright 2012 by Taylor\&Francis. Adapted with permission 
Chaston (2012) indicates four dimentions creating axes of building competitive advantage, which are transactional excellence, relationship excellence, product performance excellence and superior value excellence. Though he underlines fact, that majority of companies choose usually two of four available dimensions, which results in one of strategic positions, as shown in figure above (cf. Picture 1)

Worth mentioning is also the most developed and extended attitude presented by authors of Partners Creating Wealth (2014) blog. They indicate 14 sources of competitive advantage: localization in global markets, strategic alliance or acquisition, competitive actions, customer clusters, company-wide market orientation, strategic fit between marketing and manufacturing, implementation of strategy, human capital, employee engagement, technological change, business analytics, production system, business processes and national export promotion. Moreover they systematized them by combining into 6 groups: externally-focused strategies, internal leadership role, human resources, technology development, logistics and operations, and finally government programs.

Although the idea of competitive advantage is well described in the literature, noticeable is the lack of a direct appeal to the idea of communication in mentioned definitions. This does not mean, however, that the factor of communication (especially electronic) does not build competitive advantage. It is rather perceived as an integral component of the previously mentioned factors, particularly due to its uniqueness, so eager emphasized by quoted authors, or a marketing advantage, underlining components of cost reduction and technological advantage.

\section{Customers uniqueness, advantages of e-communication and investments in online advertising}

As own research shows (Tarabasz, 2012a, 2013b) because of the increasing popularity of Internet, both as a source of information and primarily as a marketing tool, more and more companies decide to stress their activity with usage of electronic communication tools. They are aware, that choosing e-media they may reach a target group, that is better educated and earns more than the average. In Poland these are mainly professionals, rather young $(65 \%$ of internauts are less than 35 years), that perceive the Internet as channel inextricably linked with advertisement. They see this medium as indissolubly combined with advertising, which also increase their consumption approach. From the company managers' point of view (Tarabasz, 2013a) Internet provides the possibility of on-line brand management, all day access to visitor statistics, checking-to-date sales results, but also, perhaps most importantly, the ability to contact $24 / 7$ with customers and employees and from any location, regardless time zone.

Apart from it Internet offers speed, efficiency, high ROI, full measurability, targeting precision due to cookies and geo-localization, immediate responsiveness, and enables message tailored one-to-one marketing. Similar opinions are presented 
in results of eMarketer (2005) research, conducted within media houses, employees of media agencies, their customers and researchers (cf. Picture 2).

Picture 2. advantages of investing in online advertising

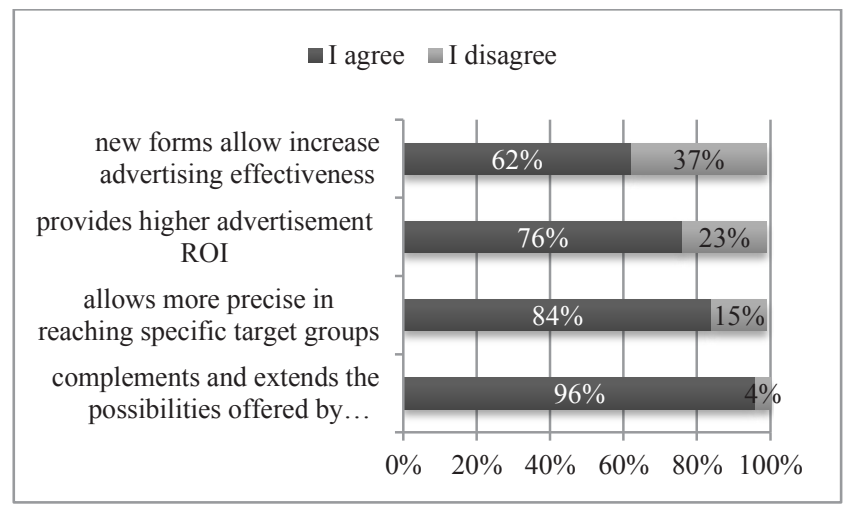

Note. own elaboration based on eMarketer.com (2005) In M. Szpunar (2007), Internet jako skuteczne narzedzie PR. In D. Tworzydło et al., Pracownicy i media w procesie komunikacji (pp. 125-135) Rzeszów: WSIiZ

Moreover, as demonstrated by the results of multistage own survey, conducted among 1,789 clients of selected 11 largest retail banks in Poland (Tarabasz, 2012a) as banks distinguishing features, $52 \%$ of respondents indicated the ,ease of use via the Internet" (what was in their opinion more important than the quality of service (41.6\%), the cheapest offer (40.8\% of responses), or even the quality of products and services $(39.3 \%$ ). In respondents opinion the most important factor building loyalty to the bank was the friendliness of selfservice via the Internet and web site $(59.8 \%$ of responses), which were more frequently indicated than the quality of service, convenience of location and the number of free ATMs (respectively 57.7\%, 57.1\% and $50.1 \%$ ).

Picture 3. Total expenditure on advertising in Poland due to used medium in given year [in mln of PLN]

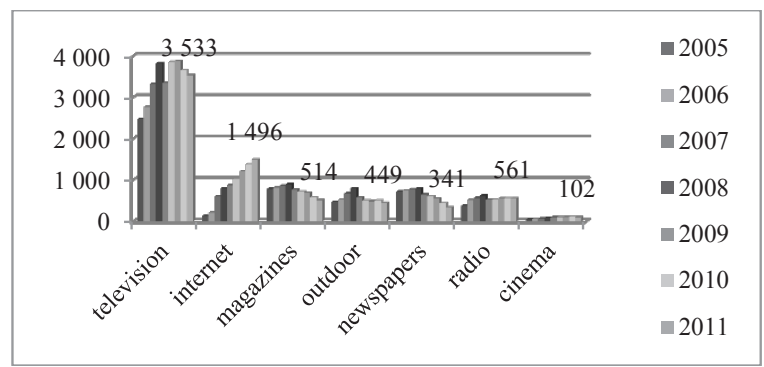

Note. own elaboration based on Starlink and Zenith Optimedia reports (Starlink 2006, 2007, 2008, 2009, 2010; Zenith Optimedia 2009, 2010, 2011, 2012, 2013, 2014) 
Taking into account the previously cited arguments, not surprising, therefore is, that the increasing number of Internet users in Poland (currently over 17.5 million in 2013) and increasing Internet penetration ratio (56.8\%) (Millward Brown SMG/KRC, 2013) nternet users are becoming increasingly attractive audience for potential advertisers. Therefore, with total value of the advertising market in Poland (PLN bn 6996) (Starlink, 2014) the Internet currently generates up to $21.4 \%$ overall advertising expenditure. It should also be noted that it is the only medium which, in chronological order (cf. Picture 3) notes as upward trend of sums invested in advertising.

\section{The model of online communication}

In the course of above presented arguments, it was demonstrated that the issue of communication with the client, using the Internet as a channel of information, is important and trully builds competitive advantage. Therefore, a verification of the existing schemes of mass communication in terms of relevance and direct application for e-reality was made (Tarabasz, 2012a, 2013a). Unfortunately, in the course of conducted analysis of 12 mass communication models, it was found, that none of them was suitable for direct implementation in order to describe electronic communication with particular emphasis on online promotion. That is why, it was decided to create such model, which, drawing on the best literature examples, would be at the same time an attempt to expand on components absent from other models, which should, however, be taken into account in this study.

Therefore, drawing from previously mentioned models of mass communication, the construction of own model, which could reflect the complexity of this phenomenon, was commenced. It main advantage, apart from strong literature study is the fact of its confirmation in practice. It took place due to practical verification by specialist of online communication and eCommerce from the banking sector and 2.5-year of participant observation.

The proposed model of online communication is built in subsequent stages, and therefore should be considered in such a manner, in order to make it more readable and easier to receive. Institution (called the advertiser) decides to undertake an advertising campaign for a specific purpose (customer acquisition, establishing a closer relationship, reminding about the product or informing about changes). But recognizes, that willing to communicate with Internauts (its current and/or potential clients), have access to them only partially. Therefore it cooperates an advertisement publishers (in analysed case such role was played by horizontal portals and sites cooperating with media houses). They are carrying out a paid advertising campaign under previously specified parameters according to campaign brief preparation. Under condition of reaching agreement on cooperation terms, advertisement publisher proposes to advertiser a specific mediaplan, which, after approval will be implemented. 


\section{Picture 4. The model of online communication and promotion}

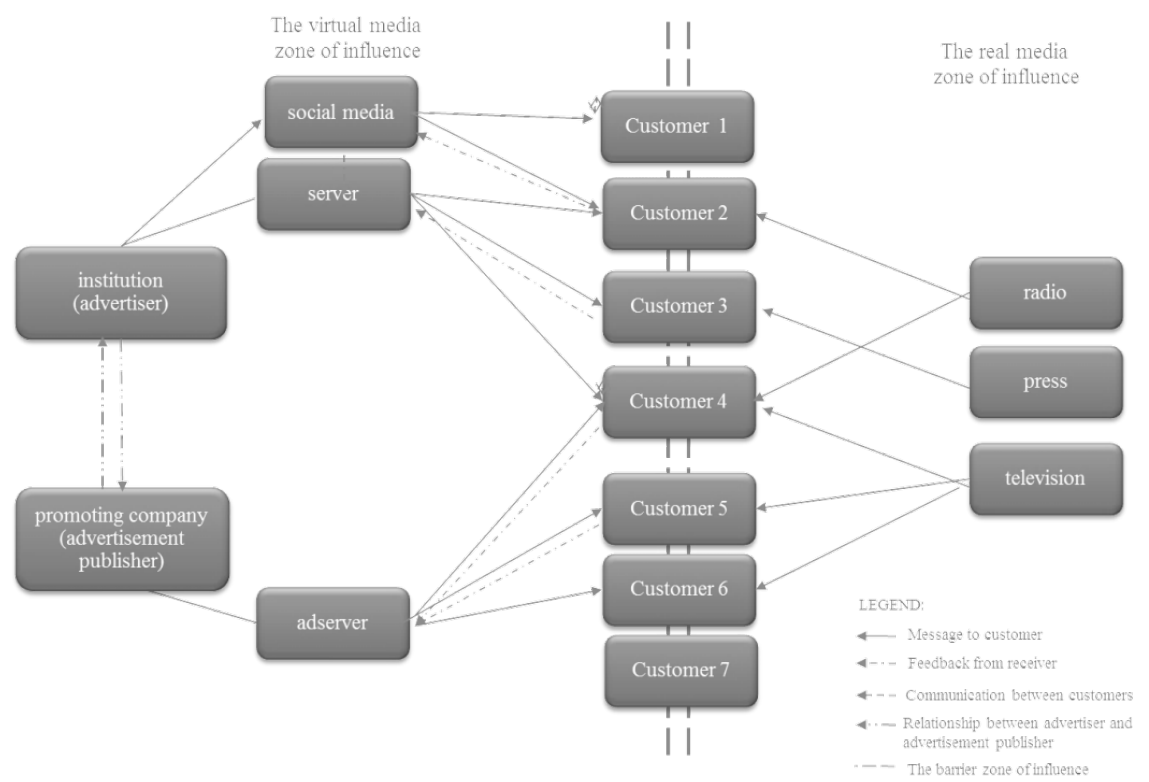

Note. A. Tarabasz A. (2013). The model and role of online communication in intercultural management, Journal of Intercultural Management 5(4), 93-103, Tarabasz A., (2012) E-komunikacja na rynku usług bankowych. Modele, narzędzia, zastosowanie, Łódź: Wydawnictwo Uniwersytetu Łódzkiego. Copyright: Wydawnictwo Uniwersytetu Lódzkiego

At the same time the institution is preparing dedicated landing page), to which internet users clicking on the ad will redirect, regardless their source of acquisition.

At the launch of campaign both institution and advertisement publisher begin to present advertisement content. Though they target the message equally to all potential customers, however, the advertiser reaches a certain group (visible in the diagram as customer 2 and 3 ). Other are informed by an external company (customers 5 and 6). There are also equally customer groups that receive both promotional messages from different senders as well as those to whom nobody can contact with (customer 7). But the most important are connections between customers themselves (1 and 3, 4 and 6), showing the social media impact and socialization itself idea.

Particularizing social media tools, and isolating them from the whole package of electronic communication tools has been done for two particular reasons. Firstly it aimed at highlight their impact on communication with customers, and underlining the importance of interaction occurring between them. Secondly introduction of this component resulted also in underlining the importance of mutual interaction between customers and institutions and thus, could be treated as an evidence of breaching the classic paradigm of one-way mass media communication. Moreover 
in course of conducted analysis was found, that by adding social media tools, new connections between customers and advertising institution occurred (shown as interaction between customers 1 and 3). Such action was also aimed at enhancing the flow of information between users themselves.

Interactivity seen in such way, available within social media aims not only at facilitating contact with the brand, but, what is far more important, offers at the same time opportunity for a dialogue with the brand, its assessment and thus constitutes a basis for creation of relationship.

And last, but not least, such actions shall be Moreover, such actions shall be mentioned separately, as, according to previously mentioned information, they constitute significant factor of competitive advantage.

\section{Underspending possibilities of the Internet and social media}

In light of the previously cited content, highlighting the importance of of communication via the Internet and building competitive advantage based on these factors, important may be results presented within the IAB Poland (2013) report. Among a representative sample of 797 active surveyed Internet users found that $90 \%$ declared usefulness of advertising when choosing the products offered on the Internet. In turn, more than $60 \%$ of the respondents mentioning promotional communications, indicated those issued in the traditional media (TV, newspapers, radio). At the same time $85 \%$ of respondents could indicate advertising forms broadcast on the Internet. Furthermore, as many as $45 \%$ of all respondents claimed that they deliberately click on online advertisements. It also appears that more than three-quarters of active Internauts use brand's nformation channels and as many as half want their favorite brands to inform about their products and services in the Internet. Furthermore, $40 \%$ of respondents claim that the websites are useful in purchases and almost every third indicated that social media brands profile tools are useful in the selection of products and services.

Data can be treated with optimism, because they underline the importance of e-media and broadcasted there promotional messages and are also significant evidence of interest in the multitude of active consumer e-media profiles social networking. Thus they prove the thesis that basing on such tools not only can, but should build competitive advantage of enterprises!

Unfortunately, companies often fail to take advantage of these possibilities. As shown by the results of research (Tarabasz, 2012a, 2012b) among the 11 largest retail banks in Poland social media tools are largely misused or poorly managed (por. Tab.1). 
Table 1 The use of electronic communication tools in 11 biggest retail banks in Poland

\begin{tabular}{|l|c|}
\hline \multicolumn{1}{|c|}{ Tool } & $\begin{array}{c}\text { Banks using praticular tools } \\
\text { (from 11 in total) }\end{array}$ \\
\hline website & 11 \\
\hline included minisite & 8 \\
\hline SEO & 5 \\
\hline SEM & 11 \\
\hline display in own portal & 7 \\
\hline display in external portals & 9 \\
\hline mailing & 5 \\
\hline newsletter & \\
\hline social media building virtual community with use \\
of: & 2 \\
\hline foras & 3 \\
\hline corporate blog & $9+1^{*}$ \\
\hline facebook & $1+1^{*}$ \\
\hline twitter & $4+3^{*}$ \\
\hline blip & 8 \\
\hline you tube & 3 \\
\hline other & 11 \\
\hline on-line PR & \\
\hline
\end{tabular}

*only profile was created

other: BZ WBK: Bank Pomysłów, nk.pl, skype; mBank: Czat, mSpołeczność, crowdsourcing, videoblog, ING Skype, video chat.

It turned out, that actions of electronic communication within those institutions reminiscent rather monologue than dialogue. Moreover, the disparity is most evident in the case of solutions in the field of social media - taking into account the multitude of available solutions in the field of social media and available marketing budgets, the forefront of Polish banking remains almost passive, or implement these solutions, but does not manage them in accurate manner (Tarabasz, 2013c). They prefer to choose one-way communication tools as website or on-line PR activities, than to manage a two-way relationship and to communicate directly, with the same "communication power" allowed by social media tools. Even the most popular Facebook was not used by all analysed companies, what is more their presence there rather have limited to single-way marketing tube (of promotional and sales tone). The more upsetting it is, as those institutions generate $75.1 \%$ of revenue from the core business of all banks, while their net profit constitutes $84.9 \%$ of the total. Realizing the fact that these institutions are considered as leaders in the indus- 
try and having the most customers and resources can afford determining market trends, it should be emphasized that actions of other institutions in this field are much more passive and inappropriate.

Partly similar reluctance of social media proper use can be found in the context of Conversocial report (2014). This study included 29 US brands with more than 5000 followers: 10 retailers, 4 airlines, 5 telecoms, 7 finance companies and 3 restaurants. It aimed ad analysis of tweets concerning customer problems or complaits. In $98 \%$ they were indicated to switch channel of communication (given e-mail address or blue line telephone number, even if they did not ask for it). In $76 \%$ those conversations did not result in a further interaction, after the brand suggested communication channel switch. What is more $42 \%$ of customer tweets were ignored by analysed brands when they ignored to switch channel. And last, but not least $-19 \%$ of customers tried suggested channel by the brand, but preferred social service.

Worth approximation are the results of underspending and misuse of social media also presentd by Evigo (2014), quoting data from the Forrester report, "The Case For Google Plus. Three Reasons Every Marketer Should Use It" z marca 2014. It turns out that even though Google Plus offers companies many users and a similar level of commitment as Twitter, many of them do not appreciate the presence there. Although Facebook is a leader in terms of number of users and the time spend on the site, this is Google Plus that offers companies greater scope and deeper commitment than could be expected. Among surveyed 60,000 adult American users of social networking sites, $22 \%$ visited Google Plus each month. Experts also analyzed the social profiles of 50 leading companies to conclude, that on Google Plus companies collected an average of $90 \%$ of the number of fans that keeps them on Twitter. It turned out that tested companies, have more users on Google Plus than on YouTube, Pinterest and Instagramie combined. However, few companies use marketing opportunities offered by this portal. In scope of the cited results more than one-third of biggest companies or does not lead profile on Google Plus or not post any content more oftern, than once a week.

Such examples of "wasted" Internet potential possibilities of social media are a lot. Companies often ineptly and clumsily manage their profiles. It seems that these tools are intended primarily to duplicate marketing messages seen in other channels and not the original purpose - building society, focusing towards the brand and facilitating dialogue. It also discourages long-term relationships and creating bonds. And yet it comes about "government of souls" and focusing around the elements and values that unite. Underspending electronic communication channel, the lack of efficient social media tools management is a conscious resignation of building a competitive advantage and distancing basis against market competitors. It is also closure of a path to the "wisdom of the crowd" - crowdsourcing, which now appears to be economical and very effective replacement to investing huge amounts in R\&D, or at least kind of "bank of ideas". 


\section{Examples of model applications in electronic communication, social media and crowdsourcing}

This does not mean, however, that not all companies are able to enjoy the benefits of the Internet and social media, and that the idea of crowdsourcing is purely theoretical being. According to Experian (2014) research results Amazon.com is the most popular portal to which are redirected Pinterest, Facebooka and YouTube users. The users of those portals visit the platform more often than any other vendor page. As is apparent from the words of Bill Tancer, general manager of Experian Marketing Services ,social media are becoming very influential source of traffic to online stores, Amazon is clearly benefiting from this trend, leading in all social networks".

Also as a good example of sodial media tools J. Crew a US-based omni-channel apparel retailer example shall be given. It proves social media presence is significant sales driver. Company reveales (Evigo, 2014b) that the customers who engage with the brand via social media spend two times more than their average customer. Crew's social media presence stretches across Facebook, Twitter, Pinterest and Instagram. Facebook is the main driver for J. Crew in terms of size and time spent on site, though company believes, that Pinterest and Instagram will be the platforms providing significant growth opportunities in the future.

But the most interesting from Internet socialization point of view are crowdsourcing projects. Using the definiction proposed by its author - Jeff Howe (2014) (see also Sloane, 2011) crowdsourcing is the act of taking a job traditionally performed by a designated agent (usually an employee) and outsourcing it to an undefined, generally large group of people in the form of an open call.

According to Innocentive (2013) remark, calling for crowdsourced ideas, information, opinions and analyses has emerged as a viable and enriched resource of enterprise-data. It is rapidly becoming a procedure of choice for generating innovative solutions for a vast range of corporate and societal issues. That is why crowdsourcing seen in such a way is not only a notion of growing polularity, but what is far more important - real proof for the need of constant cooperation and co-creation of company's ideas by internauts. Moreover - it is an incorporated idea and significant factor of competitive advantage building.

That is why, even though previously the examples of sociam media tools misuse have been presented, optimism can fill the number of projects carried out within crowdsourcing all over the World. Worth mentioning are activities of AnheuserBusch, Crowdspring, Dell, General Mills or Lego. Those examples (though being a small portion of available projects) constitute living proof that in such way crowdsourcing create an kind of tangible base for building the competitive advantage

Budweiser (2014) US probably the most drinakble bear, as brand belonging to Anheuser-Busch (AB) aimed at development of Black Crown. The aim of the proj- 
ect, that combined 12 brewmasters, who, with the use of suggestions and tastings of more than 25,000 consumer-collaborators introduced brand attuned to craft-beer tastes.

Crowdsprig (2014), launched in 2008 is treated as a marketplace of crowdsourced creative services. They connect the supply and demand for logo, web and packaging design as well as company and product name. Buyers needing a custom materials are offered actual work of specific designers, instead of bids and proposals. The project connents to more than 150,000 designers in over 41,000 of projects and more than 600 open projects, to which in total almost 5,000,000 of entries (propositions) have been offerred.

Dell (2014) Idea Storm was launched in 2007 as a way dialogue creation between the brand and communicty of its customers. Projects conducted in a form of brainstorming sesssions concentrate on new Dell's products propositions and improvement of the current product structure. Nowadays it has almost 21,000 of submited ideas, from which 547 were implemented. At the same time according to site's statistics they gained almost 750,000 of votes for particular assessed projects and obtained more than 100,000 of comments.

General Mills (2014), food-processing company introduced G-WIN (General Mills Worldwide Innovation Network) in search for innovative concepts in a variety of merchandise, commodity, or service categories. They focus on: products, their packaging, manufacturing improvements, products ingredients, technology-suggestions and improvements in company's digital efficiency.

Lego Cuusoo (2014), originates from 2008 as an crowdsourcing platform to develop new product ideas. Internauts submit potential products, find 10,000 supporters (likes). If such proposition will be assesssed positively by Lego Review, product wil be introduced to company's offer ad its founder will be granted 1\% of its total sales around the World.

\section{Conclusion}

Although there are many definitions of competitive advantage, in vain therein seek would references to the on-line communication tools. This shows the discrepancy between the theory and practice of management. It is difficult to deny Internet and its tools importance and the role they have in terms of building relationships with customers and create goodwill for strategic differentiation. Undeniably an important element appears here electronic communications, using social media tools. This previously unrecognized factor used increasingly by businesses is already not only a two-way channel of communication with the customer, but also a source of inspiration for many companies, due to the idea of crowdsourcing. Thus, in an era of change and electronic socialization of Internet users, the skilful application of e-of communication tools must discern the basis for creating relationship between 
customer and the company and what follows an important factor in building a sustainable competitive advantage.

\section{Bibliography}

Barney, J. (1991). Firm resources and sustained competitive advantage. Journal of Management 17(1), 99-120. In S. S. Sengupta (Ed.) Busines and society (p.7) New Dheli: Discovery Publishing House.

Braun P. (2006). Linking small business networks with innovation in E. Coakes, S. Clarke (Eds.) Encyclopedia of communities of practice in information and knowledge managemt (pp. 346352), Hershey, PA: Idea Group Reference

Budweiser (2014), Crowdsourcing Projects led by Anheuser-Busch, Crowdsourcing.org Retrieved from http://www.crowdsourcing.org/navigate-search?q=Budweiser 04/30/2014

Chaston, I. (2012). Strategy for sustainable competitive advantage: surviving declining demand and China's global development. New York, NY: Routledge.

Conversocial (2014), Tweet, Email or Call? Which Brands are re-directing Social Media Complaints to Traditional Channels. Best Practice Reports. Retrieved from http://www. conversocial.com/resources/best-practice-reports 04/29/2014

Crowdspring (2014), The world's \#1 marketplace for logos, design, graphic and naming, Crowdspring. Retrieved from http://www.crowdspring.com 04/30/2014

Dell (2014), Idea Storm, Dell Idea Storm. Retrieved from http://www.ideastorm.com $04 / 30 / 2014$

Evigo (2014a), Forrester: Google Plus niedoceniane przez e-sprzedawców. Evigo. Ecommerce $w$ Polsce i na świecie. Retrieved from http://evigo.pl/6519-forrester-google-plus-niedoceniane-przez-e-sprzedawcow/ 04/03/2014

Evigo (2014b), J. Crew proves social media presence is significant sales driver, Evigo. Ecommerce $w$ Polsce i na świecie. Retrieved from http://evigo.com/12582-j-crew-proves-socialmedia-presence-significant-sales-driver/ 04/30/2014

Experian (2014), The 2014 Digital Marketer. Create intelligent interactions with your customers. Every time [Electronic version], New York:Author

General-Mills (2014), Worldwide Innovation Network, General Mills G-Win Innovation Network, Retrieved from http://gwin.force.com/opportunities 04/30/2014

Howe, J. (2014), Crowdsourcing definiction, Crowdsourcing. Why the power of crowd is driving the future of business. Retrieved from typepad.crowdsourcing.com http://www/crowdsourcing.com 04/30/2014

IAB Polska (2013), eCommerce, eCommunication. Rola komunikacji w handlu elektronicznym, [Electronic version], Warsaw:Author

Innocentive (2013), 5 Examples of Companies Innovating with Crowdsourcing Innocentive. Perspectives on innovation. Retieved from http://www.innocentive.com/blog/2013/10/18/5examples-of-companies-innovating-with-crowdsourcing 10/18/2013

Khosrow-Pour M. (2005). Dictionary of Information Science and Technology, Hershey, PA: Idea Group Reference. 
Kotelnikov,V., (2007, Oct). Sustainable Competitive Advantage. 1000 Advices. Retrieved from http://www.1000advices.com/guru/strategy 10/31/2007.

Lego Cuusoo (2014) Lego Ideas, Lego Cunsoo, Retrieved from https://ideas.lego.com $04 / 30 / 2014$

Lindt, P. (2012), Communication at work, Portland, OR: Inkwater Press.

Lubbe, S. (2005). Strategic alignmet of organizational strategies. In M. Khosrow-Pour (Ed.), Dictionary of Information Science and Technology (pp. 2622-2626) Hershey, PA: Idea Group Reference.

Nissen, M.E. (2005). Delineating Knowledge Flows for Enterprise Agility. In M. Khosrow-Pour (Ed.), Dictionary of Information Science and Technology (pp. 779-785) Hershey, PA: Idea Group Reference.

Partners creating Wealth (2014, Apr.). 14 Sources of competitive advantage, Partners Creating Wealth. Retrieved from http://www.partnerscreatingwealth.com/14-sources-of-competitive-advantage/.

Porter, M. (1985). Competitive Advantage. In A. Rolstadås (Ed.), Performance management. A business process benchmarking approach, (pp. 43-44), London: Chapman\&Hall.

Porter, M.E. (1985). Competitive Advantage. New York, NY: Free Press.

Roger, S.C. (2009). The supply-based advantage: how to link suppliers to your organization's corporate strategy, New York, NY:Amacom.

Rolstadås, A. (1995). Performance management. A business process benchmarking approach, London: Chapman\&Hall.

Sengupta, S.S. (2003), Busines and society, New Dheli: Discovery Publishing House.

Sloane, P. (2011).nA guide to open innovation and crowdsourcing.. Advice from leading experts, London:Kogan Page.

Starlink (2006), Estymacja rynku reklamowego w Polsce 2006 [Electronic version], Warsaw:Author Starlink (2007), Estymacja rynku reklamowego w Polsce 2007 [Electronic version], Warsaw:Author Starlink (2008), Estymacja rynku reklamowego w Polsce 2008 [Electronic version], Warsaw:Author Starlink (2009), Estymacja rynku reklamowego w Polsce 2009 [Electronic version], Warsaw:Author Starlink (2010), Estymacja rynku reklamowego w Polsce 2010 [Electronic version], Warsaw:Author Szpunar, M. (2007), Internet jako skuteczne narzędzie PR. In D. Tworzydło \& T. Soliński (Eds.), Pracownicy i media w procesie komunikacji (pp. 125-135) Rzeszów: WSIiZ

Tarabasz, A. (2012a) E-komunikacja na rynku ustug bankowych. Modele, narz̨dzia, zastosowanie, Łódź: Wydawnictwo Uniwersytetu Łódzkiego.

Tarabasz, A. (2012b). Formy komunikacji elektronicznej z klientem banku (na podstawie przeprowadzonych badań), Handel Wewnętrzny V/VI (2), 387-395

Tarabasz, A. (2013a). The model and role of online communication in intercultural management, Journal of Intercultural Management 5(4), 93-103.

Tarabasz, A. (2013b). The reevaluation of communication in customer approach - towards 
marketing 4.0, Contemporary Management Quaterly. The Journal of Scientific Community and Business Leaders 12 (4), 124-134

Tarabasz, A. (2013c). The use of social media in the Polish retail banking in the era of marketing 3.0, Studia Ekonomiczne "La société de l'information. Perspective européenne et globale. La société de l'information et ses enjeux pour les entreprises" (150), 159-169

Tworzydło, D., \& Soliński, T. (Eds.). (2007). Pracownicy $i$ media w procesie komunikacji). Rrzeszów: WSIiZ

Zenith Optimedia (2009), Advertising Expenditure Forecasts 2009 [Electronic version], Warsaw:Author

Zenith Optimedia (2010), Advertising Expenditure Forecasts 2010 [Electronic version], Warsaw:Author

Zenith Optimedia (2010), Advertising Expenditure Forecasts 2014 [Electronic version], Warsaw:Author

Zenith Optimedia (2011), Advertising Expenditure Forecasts 2011 [Electronic version], Warsaw:Author

Zenith Optimedia (2012), Advertising Expenditure Forecasts 2012 [Electronic version], Warsaw:Author

Zenith Optimedia (2013), Advertising Expenditure Forecasts 2013 [Electronic version], Warsaw:Author 